Arab World English Journal (AWEJ) $2^{\text {nd }}$ Special Issue on Covid 19 Challenges January 2022 DOI: https://dx.doi.org/10.24093/awej/covid2.30

\title{
An Investigation of Malaysian Secondary School Teachers and Students' Perspectives towards Computer Technology in Education during the Covid-19 Pandemic
}

\author{
Rajantheran Muniandy \\ Department of Indian Studies, Faculty of arts and Social Sciences \\ University of Malaya, Kuala Lumpur, Malaysia \\ Sillalee S.Kandasamy \\ Department of Indian Studies, Faculty of arts and Social Sciences \\ University of Malaya, Kuala Lumpur, Malaysia \\ Manimaran Subramaniam \\ Department of Indian Studies, Faculty of arts and Social Sciences \\ University of Malaya, Kuala Lumpur, Malaysia \\ Atieh Farashaiyan \\ Department of English Language, Faculty of Humanities \\ Zand Institution of Higher Education, Shiraz, Iran \\ Corresponding Author: atieh_farashaiyan@yahoo.com
}

Received: 9/8/2021 Accepted:1/12/2022 Published:1/24/2022

\section{Abstract}

The present study aims at investigating the perspectives of Malaysian secondary school teachers and students towards computer technology in education during the Covid-19 Pandemic. A questionnaire adapted from Christensen and Knezek (1998) was used as a data collection instrument in this study. The participants included 49 secondary school teachers, 63 student teachers and 125 secondary school students. The main result of the study indicates that teachers have the most positive perspectives towards computers than that of student teachers and senior high school students. In contrast, senior high school students do not have positive perspectives towards the use of computer technology. In addition, they have different perspectives concerning different constructs including enthusiasm, email, vocation, aversion and enjoyment. The results of this research offer an understanding of Malaysian secondary school teachers' and students' perspectives to computer technology in education. Therefore, it can help promulgate computer usage in secondary education. In addition, the findings will inform policy-makers and stakeholders of secondary schools to prepare particular strategies for diverse targeted groups to enhance computer applications.

Keywords: Computer technology, Covid 19 pandemic, education, secondary schools, students, teachers

Cite as: Muniandy,R., Kandasamy, S.S., Subramaniam, M. , \& Farashaiyan, A. (2022). An Investigation of Malaysian Secondary School Teachers and Students' Perspectives towards Computer Technology in Education during the Covid 19 Pandemic Arab World English Journal (AWEJ) $2^{\text {nd }}$ Special Issue on Covid 19 Challenges (2) Pp. 453-465.

DOI: https://dx.doi.org/10.24093/awej/covid2.30 


\section{Introduction}

Technology has improved quickly in recent years. This enhancement is influencing the field of education. As the result of this rapid progress of technology, its usage is crucial for second and foreign language teaching and learning in higher education settings(Bond \& Bedenlier,2019). The addition of technology in English teaching and learning contexts is enormously significant for developments in four language skills. For instance, the use of computer technology has improved reading comprehension and listening performance of learners(Gairola, 2020). Some studies concentrated on the role of technology on writing improvements as well. According to Williams and Kingham (2019), technology usage supports developments in all aspects of second and foreign language learning.

Moreover, the widespread utilization of technology is quickly changing students' expectations and learning habits in language teaching settings. So, the traditional education methods become inadequate. Therefore, different ways of enhancing students' learning have been proposed by scholars (Tezci, 2019). In this regard, computer-assisted language learning has appeared with its potential to change the conventional face to face classroom context and alter learning in a new way (Raja \& Nagasubramani, 2018). Several studies showed that computerassisted language learning can offer a variety of learning outcomes and consequently engage learners more in the learning process due to an assortment of pedagogical and innovative methods (Nikolopoulou, 2020; Webster, 2017).

The use of computers in Malaysian secondary schools has increased due to the Covid-19 pandemic. Therefore, the government is spending more money to purchase more computers for schools and to train teachers to make use of them. Despite this matter, there is no information about whether teachers and students are ready to take advantage of the computer technology during the Covid-19 pandemic (Bond \& Bedenlier, 2019).

Malaysian past experiences with language laboratories revealed that many language teachers were reluctant to use language labs because of their poor knowledge and skills in operating them. Therefore, many of the machines deteriorated before teachers utilized them. One way of empowering secondary school teachers and their students to deal with computers is through understanding their perspectives and beliefs about the computer technology. Awareness of users' perspectives toward computers is a critical factor in enhancing the acceptance of computers and understanding current user behavior and shaping future behavior such as computer usage (Al-Jabri \& Al-Khaldi, 2019). While a number of studies have been conducted about the advantages of Information and Communication Technology (hereafter, ICT) in education, there is a paucity of studies about the perspectives of teachers towards them. Therefore, this study intends to explore the perspectives of Malaysian secondary school teachers and students towards computer technology in education.

\section{Literature Review}

Previous studies have illustrated different results concerning the integration of computer technology in education. Krause et al. (2017) investigated chemistry teachers' views regarding ICT use in education generally and in chemistry education particularly and their self-efficacy. The data were accumulated through a questionnaire. Two hundred and thirty-nine chemistry 
teachers took part in this study. The results demonstrated that teachers have positive attitudes toward the use of ICT.

In another research, Semerci and Aydin (2018) examined the viewpoints of high school teachers about computer technology application in education. More specifically, they investigated the differences in teachers' views based on their gender, age, teaching experience, ICT experience, ICT skills and ICT training. The subjects included three hundred and fifty high school teachers in Ankara. The results demonstrated that teachers possess a high level of enjoyment regarding computer use in their classes. Still, the above factors do not affect teachers' readiness to use computers.

Moreover, Mahdum et al. (2019) investigated the insights of senior high school teachers in Indonesian rural regions about ICT utilization in learning activities. A questionnaire was administered to collect the required data. In this research, six hundred Indonesian senior high school teachers from five rural regions participated. The findings revealed that the teachers are ready to integrate computer technology into the learning activities.

Gairola (2020) examined the perspectives of teachers and students about the utilization of computer technology in teaching and learning of mathematics in public secondary schools in Ibadan. The data collection instrument was a questionnaire with 20 items. Two hundred students and twenty teachers from ten diverse schools took part in the study. The results showed that the students were inclined to use computer technology in learning of mathematics whereas teachers were not interested in using computers in teaching mathematics.

In a recent survey, Tou et al. (2021) investigated the approaches of Singaporean teachers regarding information technology in physical education across diverse demographic groups. The participants of the study included 422 physical education teachers. To examine their attitudes towards the ICT, a questionnaire was administered in this study. The results showed that a significant difference exists between attitudes of teachers with diverse gender, age, and teaching experience towards information and communication technologies. However, their perspectives with various school levels did not differ significantly towards ICT. In addition, Alvarado et al. (2020) examined perspectives of teachers towards the practice of computer technology in Ecuadorian schools. Fifty-six teachers in Ecuador participated in this research. The results showed that due to low resources, competition among teachers, and lack of job and personal security, the praxis of ICT in schools is a challenging task.

In the Malaysian context where the use of computer technology in secondary school settings has recently been adopted by secondary school authorities due to the Covid-19 pandemic, studies about perspectives of teachers and students towards computer technology are necessary. Therefore, this study intends to investigate the perspectives of Malaysian secondary school teachers, student teachers and students towards computer technology in education during the Covid-19 pandemic.

\section{Method}

The present study adopted a common sampling technique, namely, convenient sampling allowing the researchers for data collection (Dorniye, 2003). 


\section{Participants}

The participants of this study included forty-nine secondary school teachers doing their M.A. program at a public university. In addition, sixty-three student teachers studying English Education at that university and one hundred twenty-five secondary school students from four secondary schools in Malaysia took part in this study.The participants were within the age range of 15-35. All the participants were native speakers of the Malay language. All participants expressed their satisfaction in participating in this research.

\section{Instrument}

A questionnaire consisting of fifty-five items adapted from Christensen and Knezek (1998) was used. This questionnaire measures perspectives toward computer technology in education. The constructs underpinning the questionnaire include enthusiasm, anxiety, and acceptance of computers. The questionnaire also covers perspectives toward email, adverse effects of computers, the productivity of computers for teachers, the relation between computers and vocational skills, prestige, individual productivity, computer aversion, gender bias, the importance of computers, confidence, relevance and enjoyment in using computers. The reliability index of the questionnaire was calculated using Cronbach's alpha. The overall internal consistency of the questionnaire was determined to be $0.92 \%$ which is satisfactory. In addition, three Malaysian expert professors of the related field from the school of education at the University of Malaya approved the face validity of the questionnaire. The three experts read the questionnaire carefully and confirmed its validity.

\section{Data collection Procedure}

This study consists of two procedures; pilot and actual study. The aim for the pilot study was to investigate the reliability and content validity of the questionnaire. Then, for the actual research, the researchers emailed the questionnaires to the participants and they were asked to fill in the questionnaire. At last, all the participants emailed their questionnaires to the researchers.

\section{Data analysis}

When all the questionnaires were collected, the quantitative analysis was performed to answer the research question. Therefore, the collected questionnaires were subjected to descriptive statistics namely the SPSS software. The descriptive statistics gained the mean and standard deviation between and within groups. In addition, the data was illustrated through the bar graphs.

\section{Results and Discussion}

The data from the questionnaires show that the average of the respondents' perspectives toward computers is 3.46 of 5 scales, which is a little higher than the "Undecided" score of 3. This result indicates that the respondents are still doubtful in adopting or integrating computers technology into their daily activities. This result is reasonable since the minimum score is 1.85 or above the "strongly disagree" while the maximum is 4.24 or above the "agree" level.

Table 1. Respondents' differences in perspectives towards computer technology

\begin{tabular}{|r|c|c|c|c|c|c|}
\hline & Sum of Squares & df & Mean Square & F & Sig. & \\
\hline Between Groups & 1.598 & 2 & .799 & 15.596 & .000 & \\
\hline Within Groups & 11.990 & 234 & $5.124 \mathrm{E}-02$ & & & \\
\hline Total & 13.588 & 236 & & & & \\
\hline
\end{tabular}


As the Table 1 shows, analysis of variance (ANOVA) reveals that there is a significant difference in perspectives towards computers among teachers, student teachers and senior high school students $(\mathrm{F}=15.596, \mathrm{df}=2, \mathrm{P}=0.000)$.

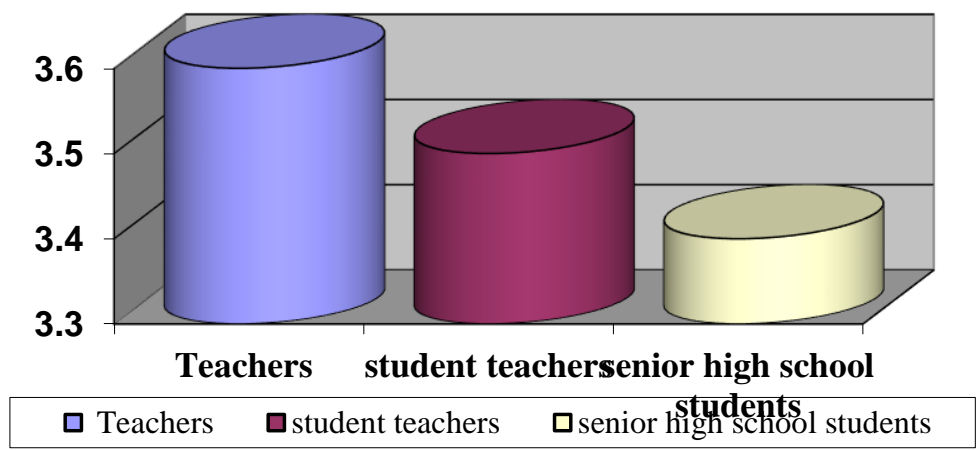

Figure 1. Respondents' differences in perspectives towards computer technology

As the Figure 1 illustrates, the average score of teachers, student teachers and senior high school students are 3.6, 3.5, and 3.4 respectively. Based on the average, we can say that teachers have the most positive perspectives towards computers followed by student teachers and senior high school students.

The interesting result is that the teachers have the most positive perspective towards computers than student teachers and senior high school students. In contrast, student teachers have a better positive attitude towards computers than senior high school students. This result may indicate that professional activities require teachers to work more with computers to realize the importance of computers in supporting their careers. It was expected that student teachers have the most positive perspective towards computers as they work more comprehensively with computers, but they did not show it. It can be discussed that students' unfavorable perspectives towards computers may be due to their lack of experience when working with computers in their campus, poor students-computer ratio, low access to computers, expensive charge, or poor elearning resources (Seraji et al., 2017; Veletsianos , 2016).

In addition, senior high school students were predicted to have a better perspectives toward computers than prospective teachers, but it is not the case. It may happen because the respondents involved were from the schools where interaction with computers is not as intense as that experienced by their cohorts of senior high schools.

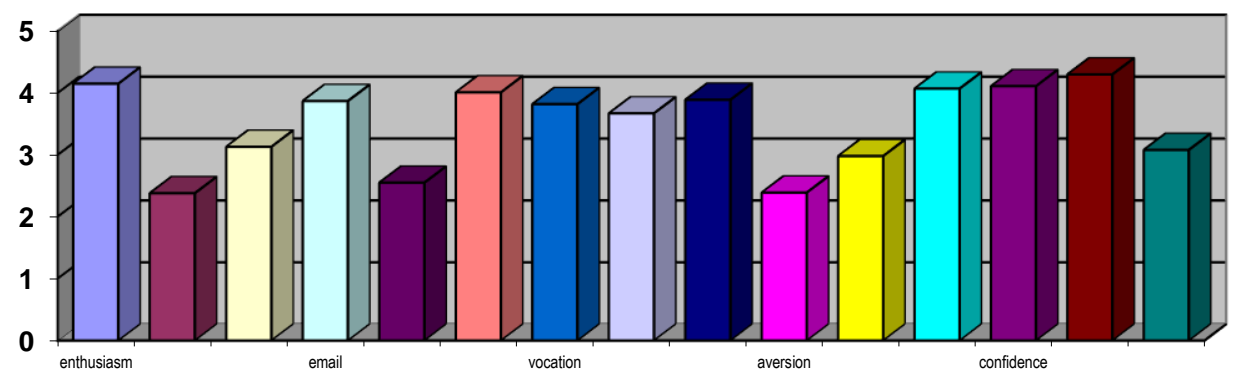

Figure 2. Respondents' differences in perspectives towards different constructs 
The above Figure shows the respondents' perspectives towards five items of enthusiasm, email, vocation, aversion and confidence. Each item is examined separately in the following sections.

Table 2. Respondents' differences in perspectives towards enthusiasm

\begin{tabular}{|l|c|c|c|c|c|c|}
\hline & & $\begin{array}{c}\text { Sum of } \\
\text { Squares }\end{array}$ & df & Mean Square & F & Sig. \\
\hline Enthusiasm & Between Groups & 4.825 & 2 & 2.412 & 9.042 & .000 \\
\hline & Within Groups & 71.769 & 269 & .267 & & \\
\hline & Total & 76.594 & 271 & & & \\
\hline
\end{tabular}

Table 2 shows the respondents' differences in perspectives towards enthusiasm. The result shows that there is a difference in perspectives towards enthusiasm among teachers, student teachers and senior high school students $(\mathrm{F}=9.042$, $\mathrm{df}=2, \mathrm{P}=0.000)$. Teachers are more enthusiastic towards computers than student teachers and senior high school students. According to Canals and Al-Rawashdeh (2019, p640), "teachers have more enthusiasm to use computers than students since they can learn online strategies in addition to conventional strategies".

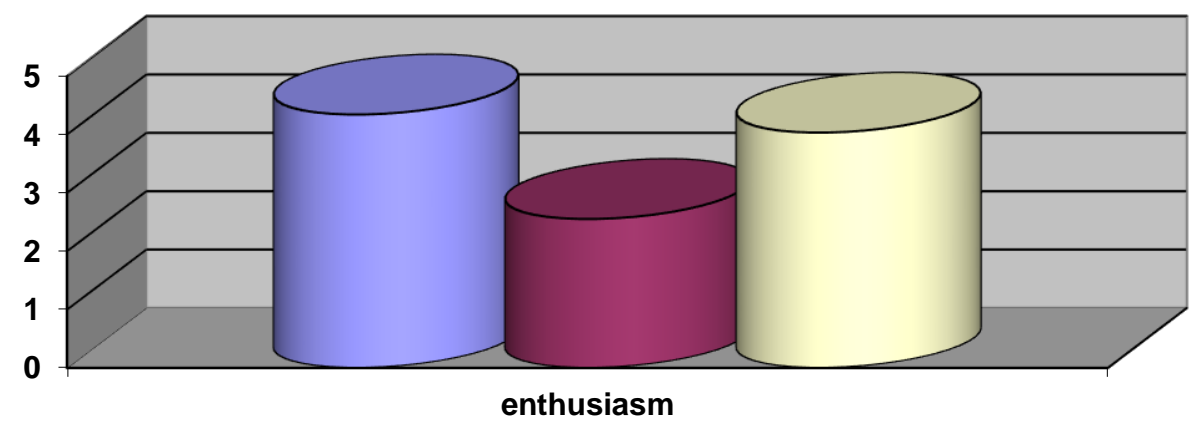

口teachers astudent teachers asenior high school students

Figure 3. Respondents' differences in Attitude towards enthusiasm

Based on the above chart, the average enthusiasm of teachers, student teachers and senior high school students are $4.35,4.25$, and 4.04 , respectively.

Table 3. Respondents' differences in perspectives towards email

\begin{tabular}{|l|c|c|c|c|c|c|}
\hline & & Sum of Squares & $\mathrm{df}$ & Mean Square & F & Sig. \\
\hline & & & & & & \\
\hline Email & Between Groups & 2.435 & 2 & 1.218 & 3.061 & .048 \\
\hline & Within Groups & 111.752 & 281 & .398 & & \\
\hline & Total & 114.187 & 283 & & & \\
\hline
\end{tabular}

The perspective of the respondents towards the use of email also differs significantly $(\mathrm{F}=$ 3.061, df $=2, \mathrm{P}=0.048)$. Teachers have the most positive perspective towards computers followed by senior high school students and student teachers. At first, it was assumed that student teachers used more email than senior high school students or teachers, but their perspective does not show this tendency. It can be discussed that the features offered by email 
can not fulfill the student teachers' communicative needs, so they are resorting to more sophisticated tools such as chatting, VoIP, blue tooth, etc. Another possible justification is that student teachers still do not use emails sufficiently to communicate with their students and improve their teaching (Canals \& Al-Rawashdeh, 2019).

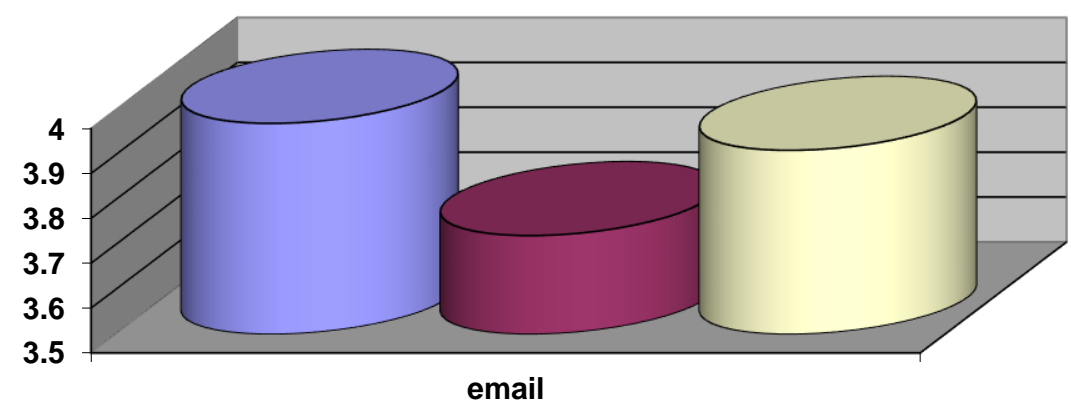

口teachers astudent teachers asenior high school students

Figure 4. Respondents' differences in perspective towards email

Based on the above chart, the average email of teachers, student teachers and senior high school students are 3.97, 3.80, and 3.70, respectively.

Table 4. Respondents differences in perspectives towards negative effect of computers

\begin{tabular}{|c|c|c|c|c|c|c|}
\hline & $\begin{array}{c}\text { Sum of } \\
\text { Squares }\end{array}$ & df & Mean Square & F & Sig. \\
\hline $\begin{array}{c}\text { Negative } \\
\text { Effect }\end{array}$ & $\begin{array}{c}\text { Between } \\
\text { Groups }\end{array}$ & 4.545 & 2 & 2.273 & 5.951 & .003 \\
\hline & Within Groups & 107.302 & 281 & .382 & & \\
\hline & Total & 111.847 & 283 & & & \\
\hline
\end{tabular}

Table 4 illustrates respondents' differences in perspectives towards negative effect of computers. The statistical analysis reveals that the three average scores differ significantly ( $F$ $=5.951, \mathrm{df}=2, \mathrm{P}=0.003$ ), meaning that senior high school students view computers to have less adverse effects on their life followed by teachers and student teachers.

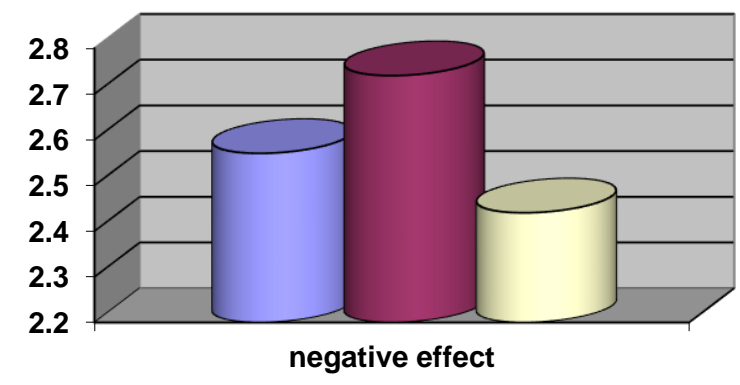

Figure 5. Respondents' differences in perspectives towards negative effect of computers 
As Figure 5 shows, all of the average scores of respondents were below three indicating that the respondents consider computers do not have adverse impact on their lives. The scores of teachers, student teachers and senior high school students are 2.57, 2.76, and 2.44, respectively. Table 5. Respondents' differences in perspective towards productivity

\begin{tabular}{|l|c|c|c|c|c|c|}
\hline & $\begin{array}{c}\text { Sum of } \\
\text { Squares }\end{array}$ & $\mathrm{df}$ & Mean Square & $\mathrm{F}$ & Sig. \\
\hline Productivity & $\begin{array}{c}\text { Between } \\
\text { Groups }\end{array}$ & 6.125 & 2 & 3.062 & 11.073 & .000 \\
\hline & Within Groups & 77.166 & 279 & .277 & & \\
\hline & Total & 83.291 & 281 & & & \\
\hline
\end{tabular}

Scores on the respondent perspectives towards computer ability to improve productivity reveal that all respondents believe that computers may enhance productivity (3.89 of 5). However, their beliefs differ significantly $(\mathrm{F}=11.073, \mathrm{df}=2, \mathrm{P}=0.000)$. Teachers show more tendencies towards the role of computers in improving productivity than student teachers and senior high school students. This situation may be related to their experiences or the length of computer use.

It can be discussed that teachers might have used computers for a longer period than both student teachers and senior high school students while interacting with students through email and so on. Therefore, teachers found computers quite helpful in doing their jobs. In addition, teachers feel that computers can contribute to their productivity but student teachers and senior high school students do not feel the contribution of computers to their productivity (Semerci \& Aydıni, 2018).
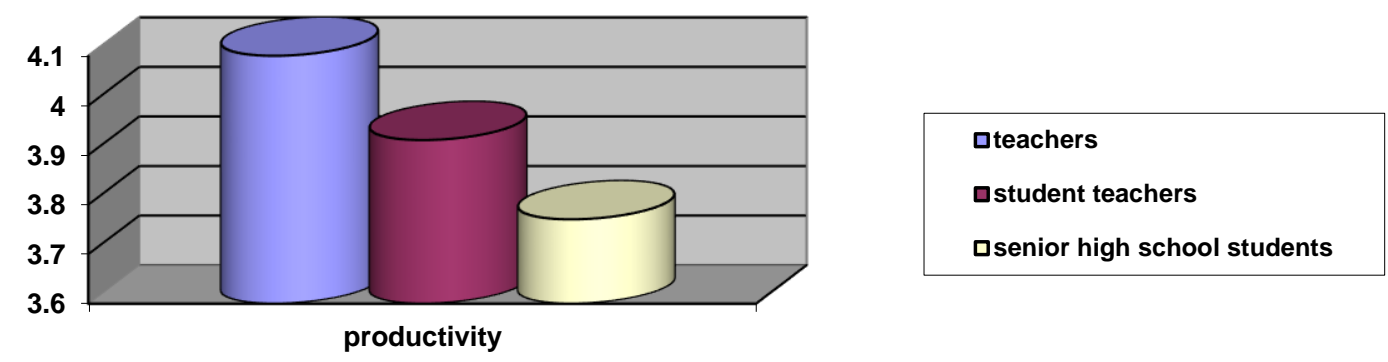

Figure 6. Respondents' differences in perspective towards productivity

The Figure 6 shows the scores of teachers, student teachers and senior high school students towards productivity which are 4.1, 3.93 and 3.77, respectively.

Table 6.Respondents' differences in perspective towards Aversion

\begin{tabular}{|l|c|c|c|c|c|c|}
\hline & & $\begin{array}{c}\text { Sum of } \\
\text { Squares }\end{array}$ & df & Mean Square & F & Sig. \\
\hline & & & & & & \\
\hline Aversion & Between Groups & 22.888 & 2 & 11.444 & 33.056 & .000 \\
\hline & Within Groups & 93.820 & 271 & .346 & & \\
\hline & Total & 116.707 & 273 & & & \\
\hline
\end{tabular}


Concerning aversion, the result illustrates that the average score of the respondents is 2.39 , meaning that they do consider that they should not avoid computers. Computers will not prevent them from being creative and they also do not need to be smart to operate computers. They also believe that all people can use computers and they also will not avoid a job requiring them to work with computers. Aversion toward computers differs significantly among the groups $(\mathrm{F}=33.05, \mathrm{df}=2, \mathrm{P}=0.000)$. The data show that senior high school students are less averted towards computers than both student teachers and teachers.
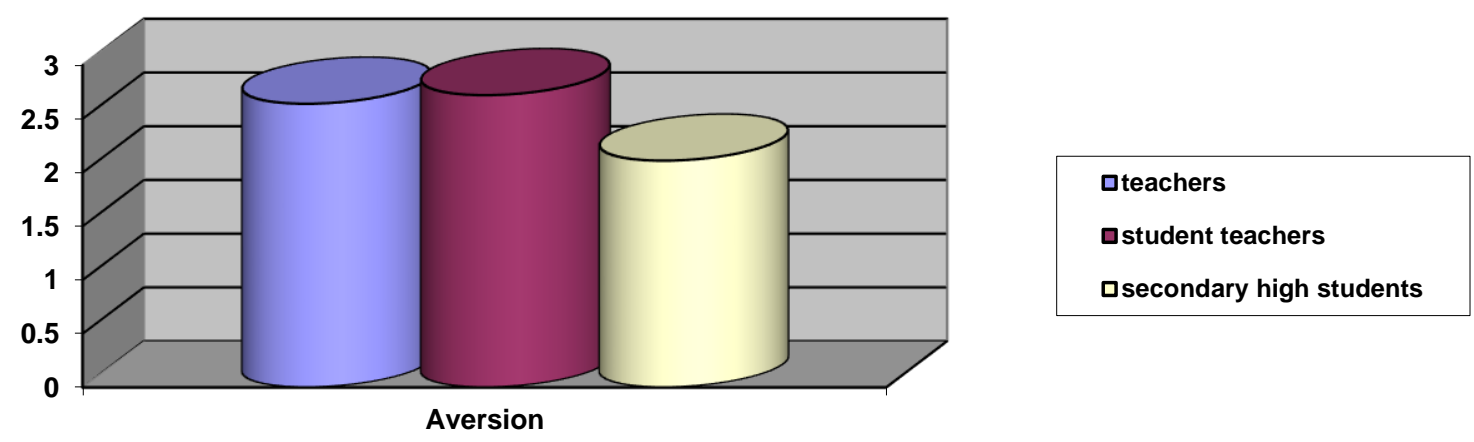

Figure 7. Respondents' differences in perspectives towards Aversion

As Figure 7 demonstrates, the scores of student teachers are higher than teachers and senior high school students. It means that student teachers have more hatred to use computers than other groups. The scores of teachers, student teachers and senior high school students towards aversion are $2.64,2.72$, and 2.17 , respectively.

Table 7.Respondents' differences in perspective towards enjoyment

\begin{tabular}{|l|c|c|c|c|c|c|}
\hline & & $\begin{array}{c}\text { Sum of } \\
\text { Squares }\end{array}$ & df & Mean Square & F & Sig. \\
\hline Enjoyment & $\begin{array}{c}\text { Between } \\
\text { Groups }\end{array}$ & 10.762 & 2 & 5.381 & 18.295 & .000 \\
\hline & Within Groups & 80.889 & 275 & .294 & & \\
\hline & Total & 91.652 & 277 & & & \\
\hline
\end{tabular}

Table 7 illustrates the differences in perspective towards enjoyment from using computers. Enjoyment towards computers differs significantly among the groups $(\mathrm{F}=18.295$, $\mathrm{df}=2, \mathrm{P}=0.000$ ). The respondents show a score which is a bit higher than the "Undecided" level (3.08) in which we can say that computers are enjoyable for them. However, the degree of enjoyment for each group of respondents is different. Computers provide more fun for student teachers than for both teacher and senior high school students. Senior high school students seem to be the group who get less fun from working with computers due to their discomfort when working with computers. This finding is partially in line with Semerci and Aydin (2018) who discovered that teachers possess a high level of enjoyment regarding computer use in their classes.

The respondents feel that computers do not make them anxious. However, they are still doubtful whether to accept them or not. However, both teachers and student teachers believe that computers could make their classroom more productive and exciting, help their vocational skills, and improve social prestige. They do not avoid computers but are still doubtful whether gender 
affects computer skills. The data also reveal that in terms of anxiety, acceptance, classroom productivity, vocational skills, prestige, aversion, gender bias, importance and relevance, there is no difference in attitude between teachers, student teachers, and senior high school students.

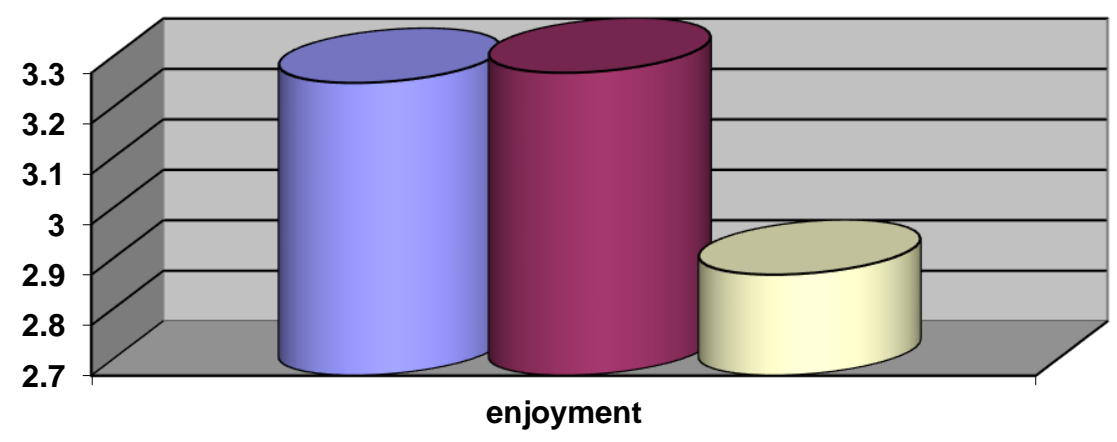

$\square$ teachers $\square$ student teachers $\square$ senior high school students

Figure 8. Respondents' differences in perspectives towards enjoyment

As Figure 8 demonstrates, the scores of student teachers are higher than teachers and senior high school students. It means that student teachers have more enjoyment to use computers than other groups. The scores of teachers, student teachers and senior high school students towards enjoyment are $3.28,3.3$, and 2.9 , respectively.

\section{Conclusion}

This study revealed that the perspectives of teachers toward computers are better than that of student teachers and senior high school students. It can be said that past experiences of teachers working with computers can play a role. To this end, it can be concluded that the teachers, student teachers, and senior high school students are between doubtful and positive. It means that they do not completely have positive perspectives to use computer technology during the Covid-19 pandemic. Therefore, school authorities have to be careful when they want to integrate computers into classroom teaching and learning activities and syllables. It seems that they understand integrating computers into their teaching and learning activities will result in positive effects, but whether they will adopt them or not is a different matter. In addition, online training can give them more confidence and knowledge to be more ready to accept and integrate computer technology into their teaching and learning activities.

\section{Limitations of the study and future research}

Although this research contributes to the literature in catering for some evidence regarding the perspectives of Malaysian secondary school teachers and students about the implementation of computer technology across diverse demographic groups, the acknowledgment of the shortcomings of the research is also essential.

The generalizability of the results of this research is the initial restriction. While the data were collected from some Malaysian secondary school teachers and students, the interpretation and generalization of the results should be done with caution due to other reasons such as biases related to technology usage that are special to diverse physical areas. Another limitation is related to the descriptive nature of this research since it can confine the degree of results-based 
deductions. Future studies can investigate the perspectives of teachers and students in other contexts. In addition, other instruments such as interview can be used to investigate the differences in teachers' perspectives towards using computer technology.

Concerning the implications, the results of this research offer an understanding of Malaysian secondary school teachers' and students' perspectives to computer technology in education. Therefore, it can help promulgate computer usage in secondary education. In addition, the findings will inform policy-makers and stakeholders of educational institutions to prepare particular strategies for diverse targeted groups to enhance computer applications. In addition, use of computer technology can be introduced in the teacher training courses to affect teachers' and student teachers perspectives in terms of utilizing computers in their classes. More importantly, secondary school students should also be informed to pay more attention to use computers in their daily activities.

\begin{abstract}
About the Authors:
Prof. Rajantheran Muniandy received his Ph.D in Literature from University Malaya and he is currently working in Department of Indian Studies, Faculty of Arts and Social Sciences, University of Malaya, Malaysia. His research interests include Indian and Malaysian studies and corpus linguistics. ORCid ID:https://orcid.org/0000-0002-3830-5075

Dr. Sillalee A/L S.Kandasamy received his Ph.D in Literature from University Malaya and he is currently working in Department of Indian Studies, Faculty of Arts and Social Sciences, University of Malaya, Malaysia. His research interests include Media, Tamil literature and culture, Malaysian Indians \& sociology. ORCid ID:https://orcid.org/0000-0002-3653-1837
\end{abstract}

Dr. Manimaran Subramaniam received his Ph.D in Literature from University Malaya and he is currently working in Department of Indian Studies, Faculty of Arts and Social Sciences, University of Malaya, Malaysia. His research interests include ethnic studies \& sociology. ORCid ID:https://orcid.org/0000-0002-7187-9345

Dr. Atieh Farashaiyan received his Ph.D in Applied Linguistics from University Kebangsaan Malaya and she is currently working in Department of English Languages, Faculty of Literature and Humanities, Zand Institute of Higher Education. Her research interests include Pragmatics, intercultural communication and corpus linguistics. ORCid ID: https://orcid.org/0000-00027265-6063

\title{
References
}

Al-Jabri, I. M. \& Al-Khaldi, M.A. (2019). "Effects of user characteristics on computer attitudes among undergraduate business students." Journal of End User Computing, 9(2), 16-23.

Alvarado, L. E., Aragón, R. R. \& Bretones, F. D. (2020). Teachers' Attitudes Towards the Introduction of ICT in Ecuadorian Public Schools. Tech Trends, 64. doi: 10.1007/s11528020-00483-7.

Arkin, E. I. (2003). Teachers' attitudes towards computer technology use in vocabulary instruction. A master's thesis. Ankara: bilkent university 
Arab World English Journal (AWEJ) 2nd Special Issue on Covid 19 Challenges January 2022

Atkins, N. E., \& Vasu, E. S. (2000). Measuring knowledge of technology usage and stages ofconcern about computing: a study of middle school teachers. Journal of Technology and Teacher Education, 8(4), 279-302.

Bond, M., \& Bedenlier, S. (2019). Facilitating student engagement through educational technology: Towards a conceptual framework. Journal of Interactive Media in Education, 1(1), 1-14. Doi: org/10.5334/jime.528

Canals, L., \& Al-Rawashdeh, A. (2019). Teacher training and teachers' attitudes towards educational technology in the deployment of online English language courses in Jordan. Computer Assisted Language Learning, 32(7), 639-Doi 10.1080/09588221.2018.1531033

Christensen, R. \& Knezek, G. (1998). Parallel Forms for Measuring Teacher's Attitudes Toward Computers. Proceedings of SITE 98. Association for the Advancement of Computing in Education: Charlotteville, VA, 831-832.

Coon, D. (1995). Introduction to Psychology. Minneapolis, MN: West Publishing.

Davies, J., \& Brember, I. (2001). The closing gap in attitudes between boys and girls: A 5-year longitudinal study. Educational Psychology, 21(1), 103-114.

Gairola, R. S. (2020). Attitudes of senior secondary school students towards computer applications in relation to their study habits. European Journal of Educational Technology, 3(1), 14-23.

Koohang, A. A. (2009). A Study of Attitudes Toward Computers: Anxiety, Confidence, Liking, and Perception of Usefulness. Journal of Research on Computing in Education, 20(1), 137-151.

Krause, M., Pietzner, V., Dori, Y,J., \& Eilks, I. ( 2017). EURASIA. Journal of Mathematics Science and Technology Education, 13(8),4405-4417. Doi:10.12973/eurasia.2017.00935a

Lee, R. (1990). Social attitudes and the computer revolution. Public Opinion Quarterly, 34(1), 53-59.

Nikolopoulou, K. (2020).Secondary education teachers' perceptions of mobile phone and tablet use in classrooms: benefits, constraints and concerns. Journal of Computers in Education, 7, 257-275.

Pancer, S. , \& Gebotys, R. J. (1992). Understanding and Predicting Attitudes Towards Computers. Computers in Human Behavior,. 8, (2), 211-222.

Raja, R., \& Nagasubramani, P. C. (2018). Impact of modern technology in education. Journal of Applied and Advanced Research, 3(1), 33-35.

Ram, S. \& Jung, H.Sh. (1994). Innovativeness in Product Usage: A Comparison of Early Adoptors and Early Majority. Psychology \& Marketing. 11(1), 5-13.

Sam, H. K., Othman, A. E. A., \& Nordin, Z. S. (2005). Computer Self-Efficacy, Computer Anxiety, and Attitudes toward the Internet: A Study among Undergraduates in Unimas. Educational Technology \& Society, 8 (4), 205-219.

Semerci,A., \& Aydini, M,K. (2018).Examining High School Teachers’ Attitudes towards ICT Use in Education. International Journal of Progressive Education, 14(2), 93-105.

Seraji, N.E., Ziabari, R.S.,\&Rokni, S.J.A. (2017). Teacher's attitudes towards educational technology in English language institutes. International Journal of English Linguistics, 7(2), 176-185. Doi:10.5539/ijel.v7n2p176

Taplin, M., \& Jegede, O. (2001). Gender differences in factors influencing achievements of distance education students. Open Learning. 16(2), 24-40.

Teo, .T., Fan, X., \& Du, J. (2015) Technology acceptance among pre-service teachers: Does gender matter?Australasian Journal of Educational Technology,31(3), 235-251. 
Tezci, E . (2019) Teachers' effect on ICT use in education: The Turkey sample. ProcediaSocial andBehavioral Sciences, 1(1), 1285-1294.

Tou,N, X., Kee,Y, H., Koh, K, T., Camire', M., \& Chow, J, Y . (2021).Singapore teachers' attitudes towards the use of information and communication technologies in physical education. European Physical Education Review, 26(2), 481-494

Veletsianos , G. (ed.) (2016).Emergence and Innovation in Digital Learning: Foundations and Applications. Athabasca, CA: Athabasca University Press

Webster, M. D. (2017). Philosophy of technology assumptions in educational technology leadership. Journal of Educational Technology \& Society, 20(1), 25-36.

Weiner, G. (1994). Feminisms in education: An introduction. Buckingham, UK: Open University.

Williams,H.S.\&Kingham,M.(2019).Infusionoftechnologyintothecurriculum.Journal of Instructional Psychology, 30(3), 178-184. 